\title{
Measuring Interest Rate Risk Considering Key Factors Affecting the Net Interest Margin (NIM) Ratio of Commercial Banks in Bangladesh
}

\author{
Raad Mozib Lalon, $\mathrm{PhD}^{1 *} \quad$ Mohammad Ali Rifat ${ }^{2}$ \\ 1.Associate Professor, Department of Banking and Insurance, Faculty of Business Studies \\ University of Dhaka, Dhaka, Bangladesh-1000 \\ 2.Department of Banking and Insurance, Faculty of Business Studies \\ University of Dhaka, Dhaka, Bangladesh-1000
}

\begin{abstract}
This paper attempts to reveal how the commercial banks operating in Bangladesh have measured interest rate risk using Interest sensitivity analysis along with considering the impact of key factors affecting the profitability measured with Net interest margin of banks under Bank specific as well as macro-economic environment. Interest sensitivity (IS) GAP analysis has been deployed to measure the degree of interest rate risk followed by a panel data regression model considering a comparative analysis among fixed effect within group, random effect GLS and Pooled OLS method adopted to measure the causation between Net interest margin and Bank specific along with Macroeconomic factor to accomplish the objective of this paper. In IS GAP along with relative IS GAP analysis, two banks are found to be liability sensitive posing a risk of reducing the net interest margin (NIM) if interest rate has been increased and rest of the banks are found to be asset sensitive again postulating risk of reducing the NIM if market rate interest has been decreased considering the ten years' data regarding rate sensitive assets (RSA) and rate sensitive liabilities (RSL) of four commercial banks selected using convenience sampling approach. Moreover, Panel Data regression model depicts how several key factors such as degree of risk aversion, credit risk and quality of management, Average operating cost, size of banks, implicit interest payments may significantly affect this NIM ratio measuring the profitability of banks in Bangladesh followed by several diagnostic tests such as model specification test using hausman \& LM test, multicollinearity test, heteroscadisticy test and unit root test conducted to check the validity of models.
\end{abstract}

Keywords: IS GAP, NIM ratio, Relative IS GAP, Fixed effect, Random effect, OLS method.

DOI: $10.7176 / \mathrm{EJBM} / 12-15-08$

Publication date:May $31^{\text {st }} 2020$

\section{Introduction}

The commercial banks of Bangladesh influence a massive part in financial prosperity of any country. Rate of interest performs a key role in a country so that it will be more important for a country to maintain the fluctuation of rate of interest in an appropriate manner through monetary policy declared by Central Bank of a country giving its full heed in the rate of interest. Conventional banks of Bangladesh perform role of supervising and maintaining the economic sector of a country that leads to the financial prosperity of a country as a whole. Interest Rate Risk (IRR) has been termed as the increase or decrease in a value of the portfolio of the bank owing to fluctuations of the rate of interest. The term is considered as the adverse condition of a financial firm because of the unfavorable reflection in the rate of interest. The term is connected with the influences of alteration in the overall financial condition. If the rate of interest decreases, then the worth of interests on deposits also gets reduced. On the other hand, the worth value of the portfolio of liabilities increases. On the other hand, the worth value of the loans and financial instruments decrease if interest rate increases Interest Rate Risk occurs because of dissimilarities of the time frame of liability \& asset. Change can occur in the IRR owing to change in the structure of asset and liabilities, amount of asset and liabilities maturity of portfolios of asset and liabilities, rate of sensitivity of asset $\&$ liabilities and the asset quality.

\section{Background of the Study}

Interest Rate Risk is one kind of risk that originates for bondholders from the fluctuation of the interest rates. Interest Rate Risk is termed as a mislaying ensuing of an unfavorable change on the cash flow and from an adverse alteration on worth of interest liabilities along with interest asset, for consequence of an increase or a decrease in the rate of interest. Private commercial banks always try to maximize the profitability of financial institutions. They try to confirm adequate amount of liquid assets to pose the firm confidence, that of the deposit makers on the expertise to serve the money provided by the depositors by giving interest in time. In order to obtain the above mentioned things, the real important thing for banks are to supervise, look after and manage the portfolio of liabilities and assets through a methodical system by receiving the consideration that different sorts of risk factors are engaged in the following arenas. The system of maintaining the financial condition has been a systematic 
decision making of the commercial banks in order to adjust or cope up with the adverse changes in the factors of risk involved. Interest Rate Risk Management of any financial firm mainly looks to reduce the risk generating factors assigned with a financial firm's overall portfolio of liability \& asset Interest Rate Risk analysis is executed through Duration Gap Analysis, Interest Sensitive Asset and Liability Analysis and Relative IS Gap Analysis. Interest Rate Risk analysis is coordinated by moving and shifting overall amount and volume of liabilities and assets of banks. The following research attempts to implement various techniques to be used in order to measure the dissimilarities of durations of asset and liability provided a sensitivity ratio and relative IS gap analysis in order to measure the Interest Rate Risk followed by an econometric modeling on the causation between NIM ratio and Bank Specific along with macroeconomic factor.

\section{Literature Review}

Many have discussed about the management of Interest Rate Risk. Basically they have followed various aspects in order to mitigate the Interest Rate Risk. Different researchers have provided different definition of Interest Rate Risk in the different aspect of banking. Beutler T. (2015) said that alteration of the rate of interest affects the financial value of portfolio of banks because this change affect the discount factor which is followed to convert the FV into PV. The financial condition of the bank also changes due to change in the net cash inflow and net cash outflow. Dash and Pathak (2011) has used a model in order to assess the liability and asset of any firm. They have observed that the government regulated banks are more successful in maintaining liquidity position than the private commercial banks. Ahmed Anwer S., Beatty Anne and Carolyn Takeda (1997) have said that the Interest Rate Risk is connected to the dissimilarities of duration between the interest sensitive asset and liability which is ISA and ISL.

Carter David (1998) has said that the interest rate derivatives can be used in order to reduce the exposures of Interest Rate Risk in the commercial banks. He has determined the Interest Rate Risk by taking maturity gap of 12 months into consideration. Deng Ran (2011) has provided some advices for the banking sector of China about the precautions regarding the prevention of Interest Rate Risk. Dhanani A. (2007) has found that the volatility of interest rate, the usage of corporate bonds affect the Interest Rate Risk Management of United Kingdom. Galai et al. (1999) has defined that the business environment of any banking organization can put an impact on the Interest Rate Risk. Bank management has been considered as a major factor in order to mitigate the Interest Rate Risk. Haslem et al. (1999) has said that the large companies with a big amount of capital tries to be more efficient while disbursing the loanable fund and put emphasis on the matching strategy of asset and liability. According to P.Allen (2000 Interest Rate Risk is lesser at community banks than in the thrift firms. He has considered the increasing asset duration as well as the excessive usage of more volatile liabilities is a primitive factor which drives to the increasing interest rate. The security portfolios are not used by banks in order to reduce this risk. Rajan and Nallari (2004) has said that more of the banks in India are liability managed. That's mean the banks are willing to manage the liabilities rather than the assets. Reeta (2013) has analyzed that in India, the rate of interest risk is regarded as the most vital risk factor for the banking institutions. It is also found that maximum institutions in India use the various gap analyses.

Shashi Srivastava (2015) measured Interest Rate Risk by using almost all sorts of methods like sensitivity analysis and duration gap analysis and has provided an advice to use derivatives in order that the firms can minimize the risk factors. For measuring the Interest Rate Risk, the banks use various techniques like gap income analysis, duration gap of asset and liability analysis, projection of net interest income, risk and return composition analysis, IS ratio analysis (Williamson, 2008). Interest Rate Risk has two dimensions namely; price \& reinvestment rate risk. The risk of price is that the change within the worth of bond owning to alterations in the rate of interest. The effective analysis for price risk is that the level of volatility in the price that is captured in a summary determined by duration, (Bierwag \& Fooladi, 2006). (Zhou.Y. and Zheng.X. ,2017) have used two factors in calculating interest rate sensitivity gap. Those are sensitivity gap and sensitivity co-efficient.

\section{Research Gaps}

As the literature has been reviewed in order to conduct the research, it has been concluded that none of any researcher has shown comparison of four banks (Basic Bank Limited, Dhaka Bank Limited, Mercantile Bank Limited and Eastern Bank Limited) simultaneously in order to show the interest rate risk considering the factors such as- NIM (Net Interest Margin), IS Gap, Relative IS Gap as well as IS Ratio followed by the formulation of econometric modeling revealing the impact of Bank specific as well as macroeconomic factor on NIM ratio measuring profitability of commercial banks.

\section{Objectives of the Study}

This paper imparts at revealing the causation between NIM and Bank specific along with macro-economic factors to demonstrate how the net interest income of banks has been affected with several factors considering micro and macro environment, finding the Interest Rate Risk management of commercial banks, estimating sensitivity of 
liabilities and assets of commercial banks and finding out the Interest Rate Risk position of commercial banks using IS GAP analysis for 10 consecutive years' data.

\section{Methodology}

6.1 Research Design

A research design identifies the overall structure of the research. A research design generally explains about how the information has been collected, what and how the tools will be conducted and analyzed. The proper tools are required to get the actual outcome from the research.

6.1.1 Type of Research

The first part of this paper has adopted only the quantitative approaches for this research study using descriptive research formed in order to present the features of measuring interest rate risk using IS GAP, relative IS GAP and IS ratio of commercial banks.

The second part of the paper is an explanatory research showing the causation between NIM being dependent variable and several Bank specific factors being explanatory variables along with macro variables to control the impact of exogenous factors.

\subsection{Data Type and sample selection procedure}

We have adopted secondary sources of data since the last 10 years collected from annual reports of 04 (four) commercial banks listed below and selected using non-probabilistic convenience sampling approach depending on the availability of data from Basic Bank Limited, Mercantile Bank Limited, Dhaka Bank Limited and Eastern Bank Limited. So, the sample size is 40 .

\subsection{Data Analysis Tools}

In order to determine and observe the numerical data which is related with Interest Rate Risk Management, various sorts of methods and procedures have been followed to get the accurate result from the calculation. For instance, in order to measure the NIM, Interest Sensitivity Ratio, IS Gap, Relative IS Gap and Duration Gap, we have taken the MS Excel as an effective tools and made graphical presentations to represent the information in a much more effective manner.

6.3.1 Analysis of Ratio: We have done two sorts of ratio analysis. These two sorts of analysis include:

a. Net Interest Margin Ratio.

b. ISA (Interest sensitive assets) to ISL (Interest sensitive liability) Ratio.

6.3.2 Analysis of Gap: We have executed two sorts of gap analysis. These two sorts of analysis include:

a. Relative Interest Sensitive Gap Analysis

b. Interest sensitivity (IS) Gap Analysis.

6.3.3 Development of Hypothesis and Econometric modeling:

Following hypothesis has been developed in order to divulge the impact of bank specific as well as macro factor on Net interest margin (NIM) of commercial banks:

$\mathrm{H}_{\mathrm{o}}$ : There is no significant relationship between NIM and Bank specific along with macro-economic factor.

$\mathrm{H}_{1}$ : There is a significant relationship between NIM and Bank specific along with macro-economic factor.

In addition, following econometric modeling has been used to test the hypothesis divulging the causation between NIM and other bank specific and macro factors using the software package STATA 12:

$$
N I M_{i t}=\alpha_{i t}+\sum_{k=1}^{7} \delta_{i t} X_{i t k}+\sum_{j=1}^{1} \lambda_{i t} Y_{i t j}+e_{i t}
$$

Here, NIM= net interest margin measured by net interest income to earning assets ratio

$\mathrm{X}_{1}=\mathrm{AOC}$ standing for average operating cost measured with operating expense to total assets ratio has been used as a proxy for showing the operating efficiency of a bank.

$\mathrm{X}_{2}=$ DORA is a proxy variable showing the Degree of bank's risk aversion measured with capital ratio calculated by dividing total equity by total assets.

$\mathrm{X}_{3}=\mathrm{CR}$ standing for credit risk measured with the ratio of loan loss provision to total loans.

$\mathrm{X}_{4}=\mathrm{SIZE}$ used as a proxy for measuring volume of operation calculated with natural logarithm of total loans

$\mathrm{X}_{5}=$ IIP standing for implicit interest payments calculated by dividing net non-interest expenditure by total assets of respective banks

$\mathrm{X}_{6}=\mathrm{OCBR}$ standing for opportunity cost of holding bank's liquid reserve estimated by the ratio of cash due from other banks to total assets 
$\mathrm{X}_{7}=\mathrm{QM}$ stands for quality of management measured by the ratio of cost to income of banks used as a proxy for managerial efficiency of banks.

$\mathrm{Y}_{1}=\mathrm{INF}$ stands for inflation measured with average inflation rate per year since 2009 used as a proxy for macroeconomic factor.

We will adopt pooled OLS ( ordinary least square) fixed effect within the groups as well as random effect GLS (generalized least square) regression methods to estimate the coefficients of the models developed earlier.

\section{Data Analysis and Discussion:}

Institutions such as banks need to determine the Interest Rate Risk frequently because wrong determination of the risk can bring about a great loss for the firm. That is why they need to be more proactive while assessing the risk. They need to use right sorts of risk measurement tools in order to mitigate the risk. Some banks use only one sort of risk mitigating tool and others try to use more methods so that they can get much more accurate result. The main Interest Rate Risk measurement techniques are as follow:

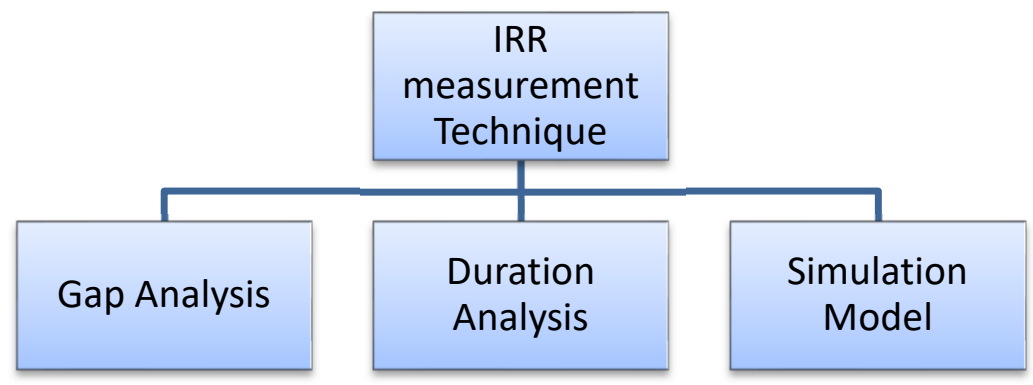

Figure 01: Techniques of Interest Rate Risk measurement

\subsection{Management of Interest Sensitive (IS) Gap}

The analysis of IS Gap is very common sort of analysis that determine the dissimilarities of the value of RSA and RSL for a specific period of time. A liability sensitive gap happens if the ISL is greater than ISA. If the liability sensitive gap occurs, the firm declines the rate of interest.

An asset-sensitive gap happens if the worth of ISA is greater than ISL for a particular period of time. To handle this sort of scenario, the bank increases the rate of interest because it will enhance spread of interest.

\section{Table 01: Types of IS Gap}

\begin{tabular}{|c|l|ll|}
\hline \multicolumn{1}{|c|}{ IS gap } & \multicolumn{1}{|c|}{ Risk } & \multicolumn{1}{c|}{ Possible Response of the Management } \\
\hline ISA $>$ ISL & $\begin{array}{l}\text { A loss generates due to } \\
\text { the decline of the interest } \\
\text { rate because net interest } \\
\text { margin of a bank } \\
\text { decreases. }\end{array}$ & $\begin{array}{l}\text { Don't do anything. } \\
\text { Needs to extend the maturity of liabilities or } \\
\text { reduce the maturities of asset. }\end{array}$ \\
\hline \hline ISL>ISA & $\begin{array}{l}\text { A loss generates due to } \\
\text { the increase the interest } \\
\text { rate because net interest } \\
\text { margin of a bank } \\
\text { decreases. }\end{array}$ & Needs to increase the ISL or to reduce ISA. \\
\hline
\end{tabular}

\subsection{Net Interest Margin (NIM) Calculation}

The NIM is termed as a profitability parameter which shows prospective analysis regarding a firm's decisions regarding the capital budgeting and investment. If Net Interest Margin (NIM) is negative, it means that the firm's interest expense exceeds the return amount thus it indicates that the firm was not at its very best while making the decision. On the other hand, if NIM is negative, it indicates that the firm's interest income is greater than interest expense. NIM is calculated through the following way shown for Dhaka Bank Ltd (DBL):

$\mathrm{NIM}=$ (Interest Income - Interest Expenses $) /$ TEA

Here,

NIM= Net Interest Margin

$\mathrm{TEA}=$ Total Earning Asset 
Table 02: NIM Calculation of DBL (2009 to 2018)

\begin{tabular}{|c|c|c|c|c|c|}
\hline Year & $\begin{array}{c}\text { Net Interest } \\
\text { Income }\end{array}$ & Total Asset & Fixed Asset & $\begin{array}{c}\text { Total Earning } \\
\text { Asset }\end{array}$ & NIM \\
\hline $\mathbf{2 0 0 9}$ & 2060 & 77767 & 424 & 45,175 & $4.56 \%$ \\
\hline $\mathbf{2 0 1 0}$ & 2460 & 90139 & 977 & 46,946 & $5.24 \%$ \\
\hline $\mathbf{2 0 1 1}$ & 2402 & 105037 & 1721 & 55,860 & $4.3 \%$ \\
\hline $\mathbf{2 0 1 2}$ & 2630 & 133142 & 1879 & 64,146 & $4.10 \%$ \\
\hline $\mathbf{2 0 1 3}$ & 3308 & 144409 & 2518 & 76,574 & $4.32 \%$ \\
\hline $\mathbf{2 0 1 4}$ & 2826 & 158748 & 3958 & 63,648 & $4.44 \%$ \\
\hline $\mathbf{2 0 1 5}$ & 2018 & 176362 & 4100 & 50,200 & $4.02 \%$ \\
\hline $\mathbf{2 0 1 6}$ & 3713 & 202191 & 4194 & 81,069 & $4.58 \%$ \\
\hline $\mathbf{2 0 1 7}$ & 3379 & 229452 & 4263 & 86,641 & $3.90 \%$ \\
\hline $\mathbf{2 0 1 8}$ & 5577 & 273976 & 4906 & 147,150 & $3.79 \%$ \\
\hline
\end{tabular}

Data Source: Annual Reports of DBL- 2009-2018

(BDT in millions)

Graph 01: NIM ratio of Dhaka Bank Limited

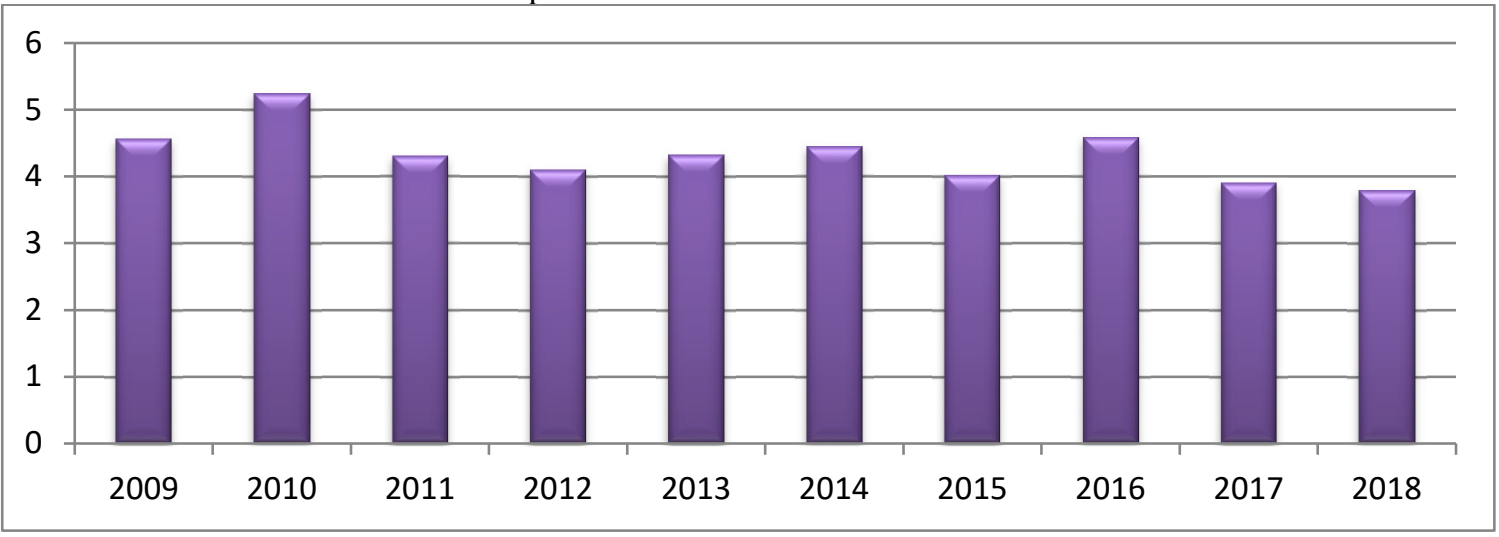

Source: Annual report of Dhaka Bank Ltd.

The table as well as graph shows us the calculation of NIM of DBL of 7 years. The NIM (Net Interest Margin) for DBL has been $4.56 \%, 5.24 \%, 4.3 \%, 4.10 \%, 4.32 \%, 4.44 \%, 4.02 \%, 4.58 \%, 3.90 \%$ and $3.79 \%$ respectively in the year of 2009-2018. The graph shows that the Net Interest Margin of Dhaka Bank Limited is not following any specific trend.

\subsection{Calculation of IS Gap}

The IS Gap is calculated by subtracting ISL from the ISA for a specific time period. A bank is considered asset sensitive if the bank's ISA is greater than that of ISL. Besides it is regarded as a liability sensitive if the bank's ISL is greater than that of ISA or the ISA is less than the ISL.

So, it can be said that IS Gap= ISA-ISL 
Table 03: IS Gap of DBL from 2009 to 2018 is given below:

\begin{tabular}{|c|c|c|c|c|c|c|}
\hline Year & ISA & ISL & IS Gap & Status & \multicolumn{2}{|c|}{ Results } \\
\hline 2009 & 15.988 & 45520 & (29532) & $\begin{array}{l}\text { Liability } \\
\text { Sensitive }\end{array}$ & 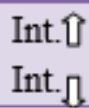 & $\begin{array}{l}\text { NIM } 8 \\
\text { NIM }\end{array}$ \\
\hline 2010 & 20657 & 47968 & (27310) & $\begin{array}{l}\text { Liability } \\
\text { Sensitive }\end{array}$ & $\begin{array}{l}\text { Int. } \widehat{\int} \\
\text { Int. }]\end{array}$ & $\begin{array}{l}\text { NIM } \\
\text { NIM }\end{array}$ \\
\hline 2011 & 35250 & 55742 & (20492) & $\begin{array}{l}\text { Liability } \\
\text { Sensitive }\end{array}$ & 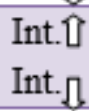 & $\begin{array}{l}\text { NIM } \\
\text { NIM }\end{array}$ \\
\hline 2012 & 37613 & 75863 & $(38250)$ & $\begin{array}{l}\text { Liability } \\
\text { Sensitive }\end{array}$ & $\begin{array}{l}\text { Int. } \\
\text { Int. }\end{array}$ & $\begin{array}{l}\text { NIM ป } \\
\text { NIM 亿ิ }\end{array}$ \\
\hline 2013 & 39236 & 80482 & $(41245)$ & $\begin{array}{l}\text { Liability } \\
\text { Sensitive }\end{array}$ & $\begin{array}{l}\text { Int. } \\
\text { Int. }\end{array}$ & $\begin{array}{l}\text { NIM } \\
\text { NIM t }\end{array}$ \\
\hline 2014 & 34953 & 79858 & (44905) & $\begin{array}{l}\text { Liability } \\
\text { Sensitive }\end{array}$ & $\begin{array}{l}\text { Int. } 0 \\
\text { Int. }\end{array}$ & 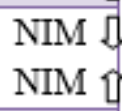 \\
\hline 2015 & 39258 & 84366 & (45108) & $\begin{array}{l}\text { Liability } \\
\text { Sensitive }\end{array}$ & $\begin{array}{l}\text { Int. } \\
\text { Int. }\end{array}$ & $\begin{array}{l}\text { NIM } \\
\text { NIM } 1\end{array}$ \\
\hline 2016 & 59899 & 95731 & (35831) & $\begin{array}{l}\text { Liability } \\
\text { Sensitive }\end{array}$ & $\begin{array}{l}\text { Int. I] } \\
\text { Int. } \Omega\end{array}$ & $\begin{array}{l}\text { NIM } \\
\text { NIM t) }\end{array}$ \\
\hline 2017 & 57549 & 111568 & (54019) & $\begin{array}{l}\text { Liability } \\
\text { Sensitive }\end{array}$ & $\begin{array}{l}\text { Int. } \widehat{\int} \\
\text { Int. } \Omega\end{array}$ & $\begin{array}{l}\text { NIM } \\
\text { NIM }\end{array}$ \\
\hline 2018 & 59868 & 141193 & $(81325)$ & $\begin{array}{l}\text { Liability } \\
\text { Sensitive }\end{array}$ & 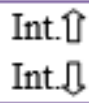 & $\begin{array}{l}\text { NIM } \\
\text { NIM I }\end{array}$ \\
\hline
\end{tabular}

Data source: Annual reports of DBL (FY 2009-FY 2018)

Graph 02: IS Gap position of Dhaka Bank Ltd (DBL)

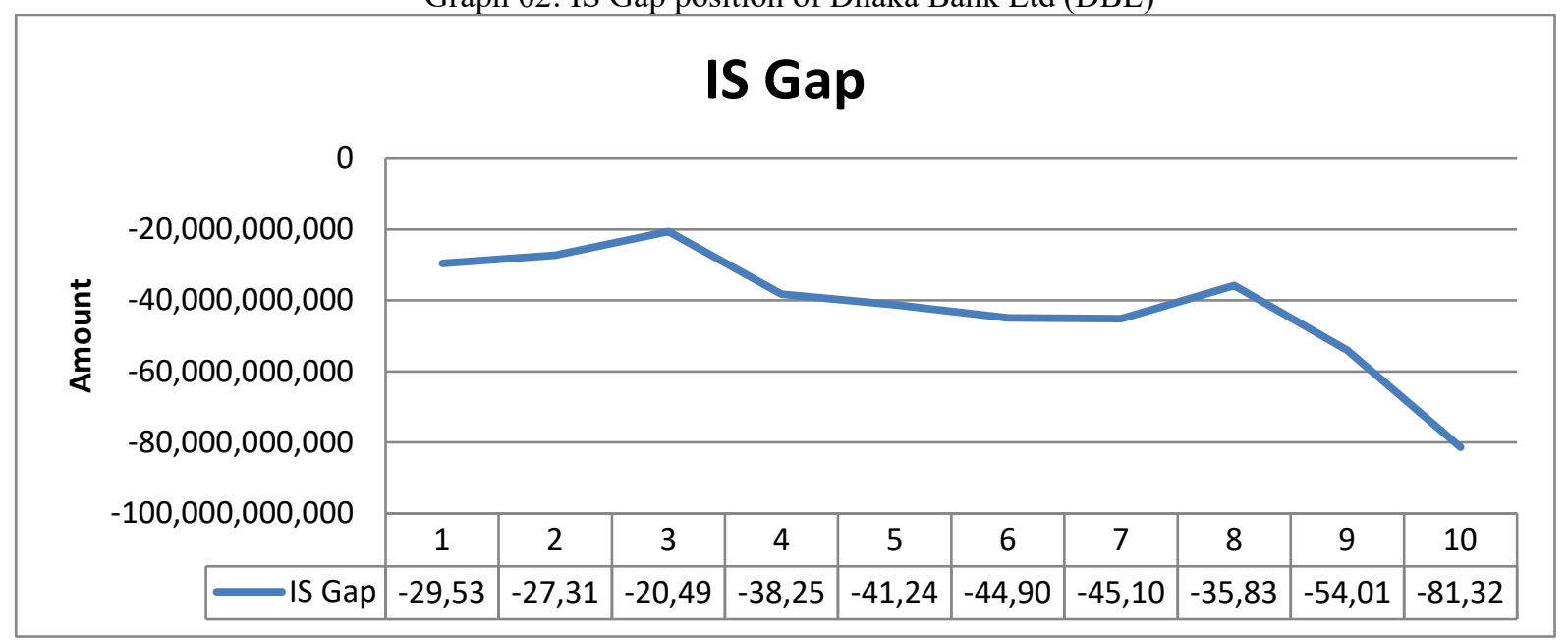

Data source: Annual reports of DBL (FY 2009-FY 2018)

Above in the table as well as graph we have the calculation of IS Gap of DBL from the year 2009 to 2018. In the year of 2009 to 2018, the status has been liability sensitive which means that the ISL was greater than ISA. When the status is liability sensitive, if the rate of interest rises, the NIM falls and if the rate falls, the NIM increases. The graph is showing that the gap has been in a decreasing trend and it has been falling more than usual. The reason can be that the bank is has not been taking its investment decisions correctly.

\subsection{Calculation of Relative IS Gap}

The relative IS Gap can be determined by dividing the Interest Sensitive (IS) gap with Total Asset of the bank or any financial institution. Thus, if the IS Gap shows a positive result, the Relative Interest Sensitive Gap will show a positive result and vice versa. 
Table 04: Calculation of Relative IS Gap of Dhaka Bank Ltd (DBL) (2012 to 2018)

\begin{tabular}{|c|c|c|c|}
\hline Year & IS Gap & Total Asset & Relative IS Gap \\
\hline $\mathbf{2 0 0 9}$ & $(29532)$ & 77767 & $(0.38)$ \\
\hline $\mathbf{2 0 1 0}$ & $(27310)$ & 90139 & $(0.30)$ \\
\hline $\mathbf{2 0 1 1}$ & $(20491)$ & 104725 & $(0.19)$ \\
\hline $\mathbf{2 0 1 2}$ & $(38250)$ & 133,142 & $(0.28)$ \\
\hline $\mathbf{2 0 1 3}$ & $(41245)$ & 145,400 & $(0.28)$ \\
\hline $\mathbf{2 0 1 4}$ & $(44905)$ & 158,747 & $(0.28)$ \\
\hline $\mathbf{2 0 1 5}$ & $(45108)$ & 177,214 & $(0.25)$ \\
\hline $\mathbf{2 0 1 6}$ & $(35831)$ & 202,191 & $(0.17)$ \\
\hline $\mathbf{2 0 1 7}$ & $(54019)$ & 230,828 & $(0.23)$ \\
\hline $\mathbf{2 0 1 8}$ & $(81325)$ & 275,397 & $(0.29)$ \\
\hline
\end{tabular}

Data source: Annual reports of DBL (FY 2012-FY 2018)

Graph 03: Relative IS Gap position of Dhaka Bank Ltd (DBL)

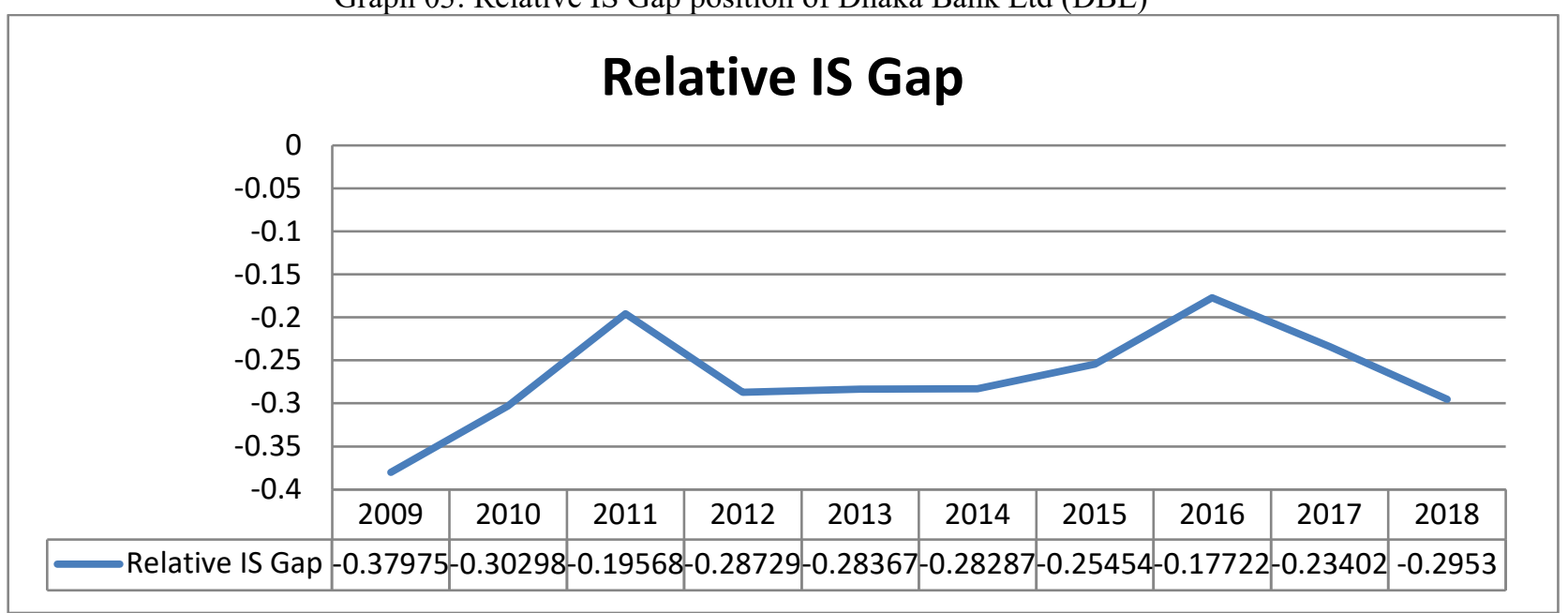

Data source: Annual reports of DBL (FY 2012-FY 2018)

The bank or financial firm is termed as asset sensitive provided the Relative Interest Sensitive Gap $>0$, which means it will provide a positive result. On the other hand, the bank or financial firm is regarded as a liability sensitive provided the Relative Interest Sensitive $\mathrm{Gap}<0$, which means it will provide a negative result. The table shows the result of Relative IS Gap of DBL from the year 2009 to 2018. It shows that in all these years Relative IS Gap has been negative for DBL. On the basis of these information, it can be concluded that DBL is more like an institution with liable sensitivity.

\subsection{Calculation of Interest Sensitive (IS) Ratio}

IS Ratio can be determined by dividing the ISA with the ISL. This indicates the efficiency of Interest Rate Risk Management. If the ISA is greater than the ISL, it will bring a positive result. Besides, if the ISA is lesser than the ISL, it will bring a negative result. 
Table 05: Calculation of IS Ratio of Dhaka Bank Ltd (From 2009 to 2018)

\begin{tabular}{|l|c|c|c|c|c|}
\hline Year & ISA & ISL & IS Gap & IS Ratio & Result \\
\hline $\mathbf{2 0 0 9}$ & 15.988 & 45520 & $(29532)$ & 0.35 & Liability Sensitive \\
\hline $\mathbf{2 0 1 0}$ & 20657 & 47968 & $(27310)$ & 0.43 & Liability Sensitive \\
\hline $\mathbf{2 0 1 1}$ & 35250 & 55742 & $(20492)$ & 0.63 & Liability Sensitive \\
\hline $\mathbf{2 0 1 2}$ & 37613 & 75863 & $(38250)$ & 0.49 & Liability Sensitive \\
\hline $\mathbf{2 0 1 3}$ & 39236 & 80482 & $(41245)$ & 0.48 & Liability Sensitive \\
\hline $\mathbf{2 0 1 4}$ & 34953 & 79858 & $(44905)$ & 0.43 & Liability Sensitive \\
\hline $\mathbf{2 0 1 5}$ & 39258 & 84366 & $(45108)$ & 0.46 & Liability Sensitive \\
\hline $\mathbf{2 0 1 6}$ & 59899 & 95731 & $(35831)$ & 0.62 & Liability Sensitive \\
\hline $\mathbf{2 0 1 7}$ & 57549 & 111568 & $(54019)$ & 0.51 & Liability Sensitive \\
\hline $\mathbf{2 0 1 8}$ & 59868 & 141193 & $(81325)$ & 0.42 & Liability Sensitive \\
\hline
\end{tabular}

Data source: Annual reports of DBL (FY 2009-FY 2018)

(BDT in millions)

Graph 04: IS Ratio of Dhaka Bank Ltd (DBL)

\section{IS Ratio}

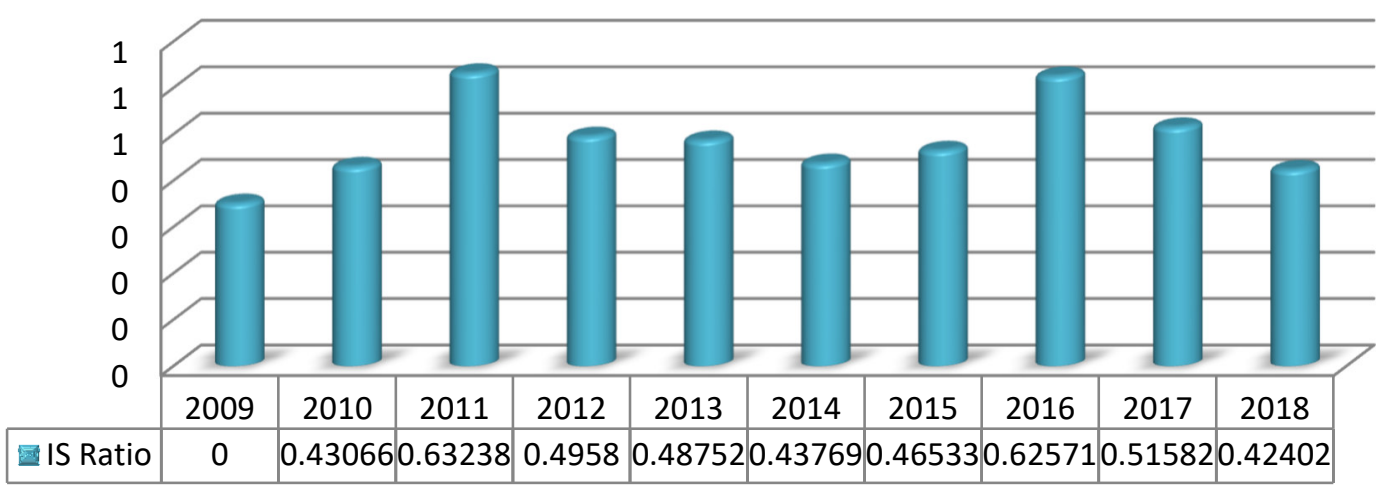

Data source: Annual reports of DBL (FY 2009-FY 2018)

Above table and graph represent the IS ratio of DBL. From the year 2009 to 2018, the IS Ratio was liability sensitive for the DBL because all these years IS Ratio was less than 1, this indicates that ISL>ISA.

\subsection{Comparative Discussion}

For a comparative discussion we have chosen another three banks to observe the position of DBL. These banks are Basic Bank Limited, Mercantile Bank Limited and Eastern Bank Limited. A comparison has been made among these banks. Thus the competitive positioned will be figured out. Comparison will be made on the basis of NIM (Net Interest Margin), IS Gap, Relative IS Gap and IS Ratio. 
7.6.1 Comparative NIM Position among four Banks

Graph 05: Net Interest Margin (NIM) ratio of Banks

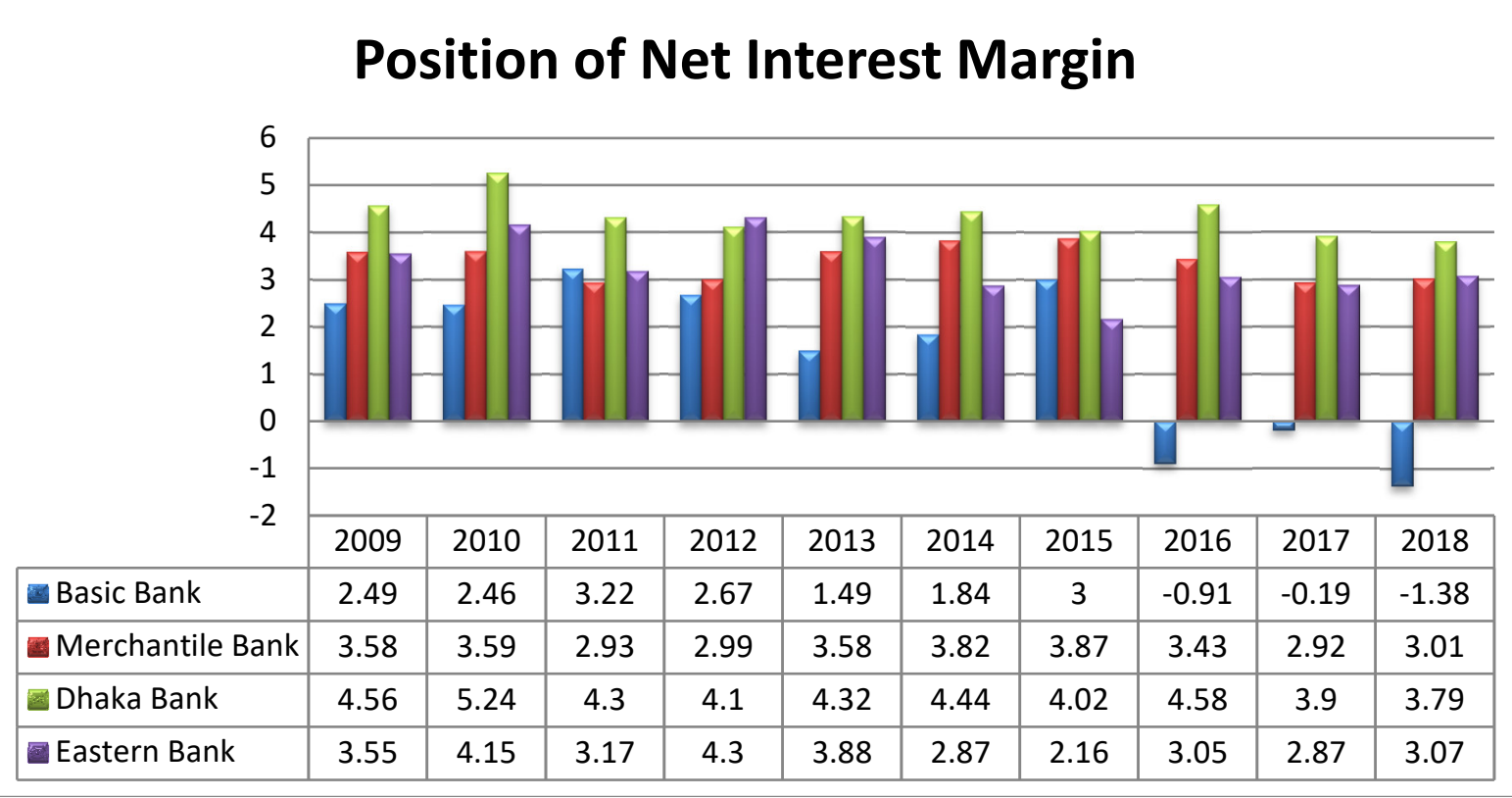

Data source: Annual reports of four Banks (FY 2009-FY 2018)

The graph shows that among these four banks the net interest position of Basic Bank Limited is very much inconsistent as well as negative in last few years. The net interest margin positions of rest of the banks are also fluctuating. The NIM Position of Dhaka Bank Limited is higher than the rest of the banks.

7.6.2 Comparative IS Gap Position among four Banks

Graph 06: Interest Sensitivity (IS) GAP Position of Banks

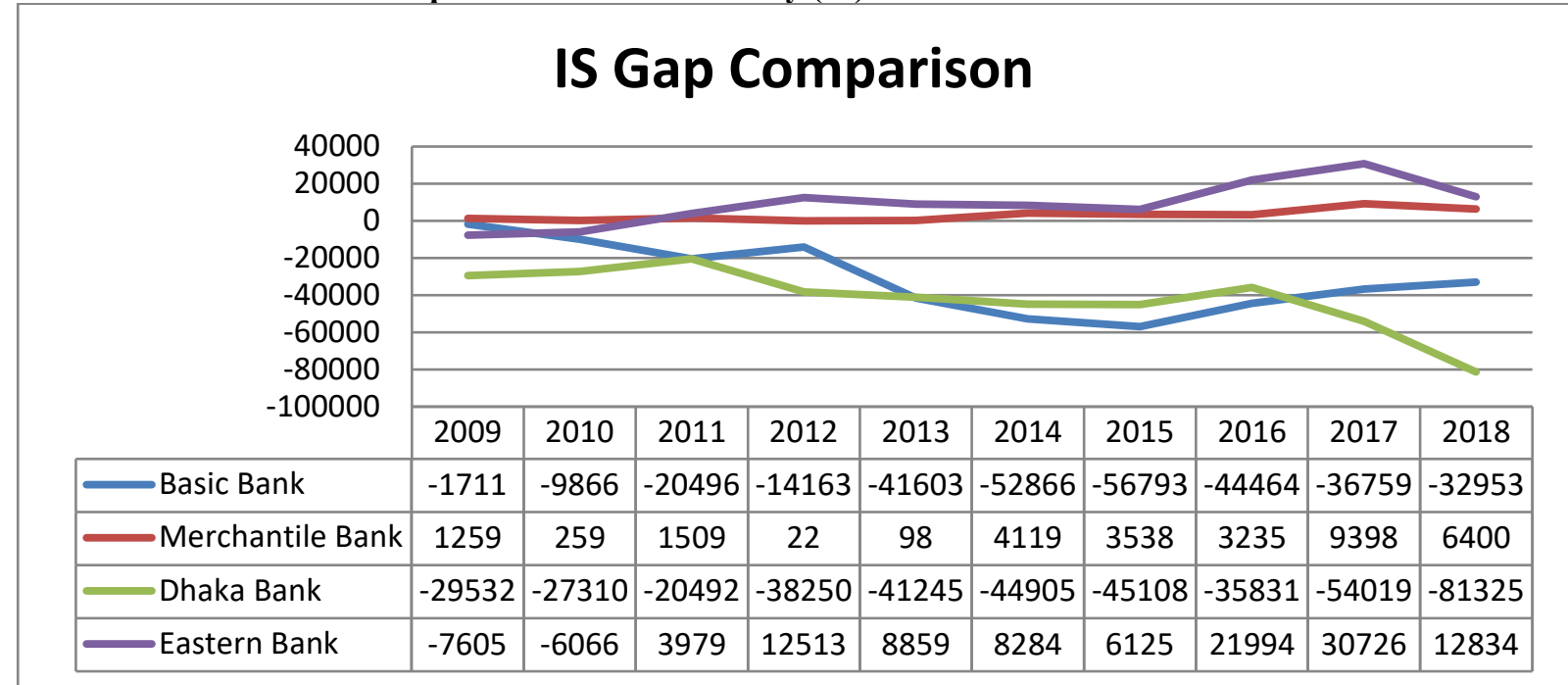

Data source: Annual reports of four Banks (FY 2009-FY 2018)

From the graph, it can be seen that Basic Bank Limited, Dhaka Bank Limited are Liability Sensitive Organizations. On the other hand, Mercantile Bank Limited and Eastern Bank Limited are Asset Sensitive Organizations. As Basic Bank Limited and Dhaka Bank Limited are Liability Sensitive, they will be in better position if the interest rate decreases and they will be in a spot of bother if the interest rate increases. Mercantile Bank Limited and Eastern Bank Limited on the other hand, will be beneficial if the interest rate increases and they will face problems if the interest rate falls. Among these four banks Mercantile Bank Limited poses the best position as its IS Gap is lesser than the rest of the banks and the results are more consistent compared to other banks. The gap between the interest sensitive assets and interest sensitive liability is huge for Dhaka Bank Limited. It means that it is not efficiently managing its ISA and ISL. 


\subsubsection{Relative IS Gap Position of Banks}

Graph 07: Relative Interest Sensitivity (IS) GAP Position of Banks

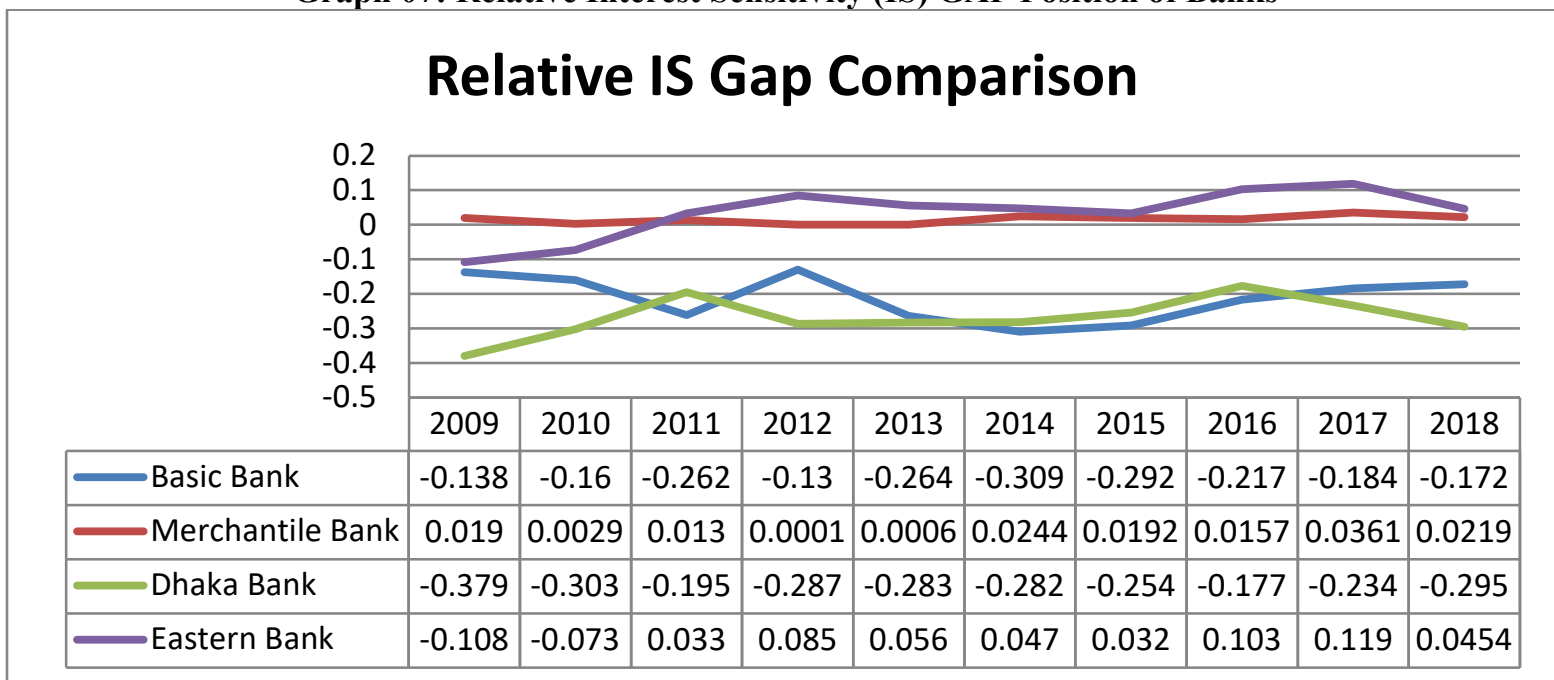

Data source: Annual reports of four Banks (FY 2009-FY 2018)

The graph shows that the relative IS gap of Basic Bank Limited and Dhaka Bank Limited is more than zero. It means that these two banks are liability sensitive. On the other hand, Mercantile Bank Limited and Eastern Bank Limited are Asset Sensitive Organizations as their relative IS gap is less than zero. As Basic Bank Limited and Dhaka Bank Limited are Liability Sensitive, they will be in better position if the interest rate decreases and they will be in a spot of bother if the interest rate increases. Mercantile Bank Limited and Eastern Bank Limited on the other hand, will be beneficial if the interest rate increases and they will face problems if the interest rate falls. Mercantile Bank Limited has the best position among these banks as the relative IS gap is more close to zero and the relative IS gap is more consistent than that of other banks. The Relative IS Gap of Dhaka Bank Limited is inconsistent and not that much great as compared to other banks.

7.6.4 Comparative IS Ratio of Banks

Graph 08: Interest Sensitivity (IS) Ratio of Banks

\begin{tabular}{|c|c|c|c|c|c|c|c|c|c|c|}
\hline \multirow{6}{*}{$\begin{array}{r}1.8 \\
1.6 \\
1.4 \\
1.2 \\
1 \\
0.8 \\
0.6 \\
0.4 \\
0.2 \\
0\end{array}$} & \multirow{5}{*}{\multicolumn{2}{|c|}{ 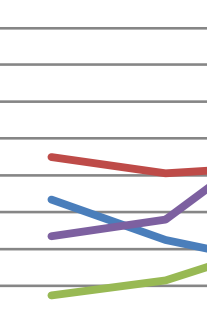 }} & & & & & & \multirow{2}{*}{\multicolumn{2}{|c|}{$\longrightarrow$}} & \multirow{3}{*}{$\nabla$} \\
\hline & & & & & & & & & & \\
\hline & & & & & & & & & & \\
\hline & & & & & & & & & & \\
\hline & & & & & & & $=$ & & & \\
\hline & 2009 & 2010 & 2011 & 2012 & 2013 & 2014 & 2015 & 2016 & 2017 & 2018 \\
\hline Basic Bank & 0.87 & 0.65 & 0.52 & 0.71 & 0.4 & 0.44 & 0.32 & 0.38 & 0.4 & 0.46 \\
\hline Merchantile Bank & 1.1 & 1.01 & 1.05 & 1 & 1 & 1.13 & 1.07 & 1.05 & 1.14 & 1.09 \\
\hline Dhaka Bank & 0.35 & 0.43 & 0.63 & 0.49 & 0.48 & 0.43 & 0.46 & 0.62 & 0.51 & 0.42 \\
\hline Eastern Bank & 0.67 & 0.76 & 1.22 & 1.43 & 1.23 & 1.19 & 1.12 & 1.46 & 1.54 & 1.21 \\
\hline
\end{tabular}

Data source: Annual reports of four Banks (FY 2009-FY 2018)

As the IS Ratio of Basic Bank Limited and Dhaka Bank Limited is less than 1, so these banks can be termed as Liability Sensitive banks. On the other hand, Mercantile Bank Limited and Eastern Bank Limited has the IS ratio of more than 1. That means these banks are Asset Sensitive. Among these banks, Mercantile Bank Limited has the best position as the IS Ratio of this bank is more close to 1 compared to other banks. The IS Ratio of Dhaka Bank Limited is not that much great. 
7.7 Econometric modeling with Random Effects, Fixed Effects and Pooled OLS

According to the coefficients estimated by Random Effect GLS (generalized least square method) method as per following table, only credit risk and quality of management followed by cr and qm variables respectively are found statistically significant in explaining the variation of net interest margin ratio followed by nim being dependent variable to reveal the changes in net interest income of banks. Credit risk measured with the ratio of loan loss provision to total loan of bank is found positively related with net interest margin ratio as higher credit risk pushes the bank to increase the net interest margin in order to cover the excess provision kept against the high probability of default loan. Moreover, quality of management measured with the ratio of Cost to Income of bank is found inversely related with net interest margin ratio because high ratio of cost to income reveals operating inefficiency of banks propelling into high NIM to cover the operating cost of banks. All other variables are found statistically insignificant in explaining the variation of net interest margin of bank. The overall $\mathrm{R}$ square value of 0.6935 divulges that $69.35 \%$ variability in net interest margin has been explained by the fitted regression model estimated by Random Effect GLS method. The Chi-square value of 70.15 is also found statistically significant considering the assumption that all explanatory variables such as average operating cost, degree of risk aversion, credit risk, size of operation, implicit interest payment, opportunity cost of holding bank's liquid reserve, quality of management and inflation are jointly significant in explaining the variation of net interest margin of bank as depicted from the following table:

Table 06: Estimators of model using Random effect (re), Fixed effect (Fe) and Pooled OLS method

\begin{tabular}{|c|c|c|c|}
\hline Variable & re & fe & pooled_ols \\
\hline $\begin{array}{r}\text { aoc } \\
\text { dora } \\
\text { cr } \\
\text { size } \\
\text { iip } \\
\text { ocbr } \\
\text { qm } \\
\text { infl } \\
\text { cons }\end{array}$ & $\begin{array}{l}-.12153597 \\
.09020243 \\
.63958188 * * \\
-.00241451 \\
-.59616257 \\
-.1004714 \\
-.08777049 * * * \\
-.06028661 \\
.18229187\end{array}$ & $\begin{array}{r}-.09817439 \\
.17983005 * \\
.42236952 * \\
-.00494423 \\
.03653935 \\
-.13376548 \\
-.06009013 * * * \\
-.107387 \\
.20688831 *\end{array}$ & $\begin{array}{l}-.12153597 \\
.09020243 \\
.63958188 * * \\
-.00241451 \\
-.59616257 \\
-.1004714 \\
-.08777049 * * * \\
-.06028661 \\
.18229187\end{array}$ \\
\hline $\begin{array}{r}\mathrm{N} \\
\mathrm{r2} \\
\mathrm{F} \\
\text { rho } \\
\text { chi2 }\end{array}$ & $\begin{array}{r}40 \\
0 \\
70.14564\end{array}$ & $\begin{array}{r}40 \\
.69130889 \\
7.8381951 \\
.62873941\end{array}$ & $\begin{array}{r}40 \\
.69351126 \\
8.768205\end{array}$ \\
\hline
\end{tabular}

legend: $* \mathrm{p}<0.05 ; * * \mathrm{p}<0.01 ; * * * \mathrm{p}<0.001$

Source: Output developed by STATA 12.0

Apart from the credit risk and quality of management, degree of risk aversion and opportunity cost of holding liquid reserve of banks followed by dora and ocbr respectively are also found statistically significant in explaining the variation of net interest margin ratio followed by nim being dependent variable to show the changes in net interest income of banks as per the output revealed by Fixed effect regression model. The degree of risk aversion measured by capital ratio calculated with dividing equity capital by total assets of bank is found positively related with net interest margin as banks increase the NIM to cover the higher cost of equity financing compared to debt financing. In addition, Opportunity cost of holding bank's reserve measured by dividing cash due from other banks by total assets is found inversely related with net interest margin ratio as higher liquid reserve increases the opportunity cost for banks and thus reduces the profitability of banks measured by NIM. On the contrary, all other variables are found statistically insignificant in explaining the variation of net interest margin of bank. The overall $\mathrm{R}$ square value of 0.6047 divulges that $60.47 \%$ variability in net interest margin has been explained by the fitted regression model estimated by Fixed effect method. The F - value of 7.84 is also found statistically significant considering the assumption that all explanatory variables such as average operating cost, degree of risk aversion, credit risk, size of operation, implicit interest payment, opportunity cost of holding bank's liquid reserve, quality of management and inflation are jointly significant in explaining the variation of net interest margin of banks. The rho value also known as intra-class correlation value of 0.6287 reveals that $62.87 \%$ variability in NIM is explained by the differences across panels. Moreover, there is no strong evidence that the model suffers from endogenity problem as the correlation value between residual within groups and the regressors (explanatory variables) is found 0.0941 .

According to the output estimated by Pooled OLS method, only credit risk and quality of management variable are found statistically significant in explaining the variation in net interest margin of banks which resemble the output estimated by Random Effect method as described earlier. 
7.7.1 Model Specification Tests:

a) Using Hausman test (Random effect vs Fixed effect)

According to the output of Hausman test mentioned below to determine between fixed or random effects method, the null hypothesis is that the preferred model is random effect vs the alternative is fixed effect (Green 2008). In fact, it tests whether the unique errors followed by $u_{i}$ are correlated with regressors, the null hypothesis is they are not. As the Chi-square value of 31.73 is statistically significant at $1 \%$ level of significance, we can reject the null hypothesis and conclude that Fixed effect model is preferable to Random effect model.

- hausman re fe

Table 07: Output of Hausman Test

\begin{tabular}{|c|c|c|c|c|}
\hline & $\begin{array}{c}\text { - coeft } \\
\text { (b) } \\
\text { re }\end{array}$ & $\begin{array}{r}\text { ients } \\
\text { (B) } \\
\mathrm{fe}\end{array}$ & $\begin{array}{c}(b-B) \\
\text { Difference }\end{array}$ & $\begin{array}{c}\operatorname{sqrt}\left(\text { diag }\left(V_{-} \_b-V_{-} B\right)\right. \\
\text { S.E. }\end{array}$ \\
\hline $\begin{array}{r}\text { aoc } \\
\text { dora } \\
\text { cr } \\
\text { size } \\
\text { iip } \\
\text { ocbr } \\
\text { qm } \\
\text { infl }\end{array}$ & $\begin{array}{r}-.121536 \\
.0902024 \\
.6395819 \\
-.0024145 \\
-.5961626 \\
-.1004714 \\
-.0877705 \\
-.0602866\end{array}$ & $\begin{array}{r}-.0981744 \\
.17983 \\
.4223695 \\
-.0049442 \\
.0365393 \\
-.1337655 \\
-.0600901 \\
-.107387\end{array}$ & $\begin{array}{r}-.0233616 \\
-.0896276 \\
.2172124 \\
.0025297 \\
-.6327019 \\
.0332941 \\
-.0276804 \\
.0471004\end{array}$ & $\begin{array}{r}1764074 \\
.049157 \\
.1429555 \\
.0019476 \\
.1915383 \\
.0285734 \\
.0090494 \\
.0688687\end{array}$ \\
\hline
\end{tabular}

$\mathrm{b}=$ consistent under $\mathrm{HO}$ and $\mathrm{Ha}$; obtained from xtreg

Test: Ho: difference in coefficients not systematic

$$
\begin{aligned}
& \operatorname{chi} 2(8)=(b-B)^{\prime}\left[\left(V_{-} b-V_{-} B\right) \wedge(-1)\right](b-B)
\end{aligned}
$$

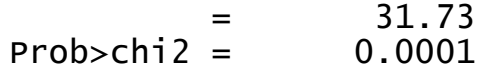

$$
\begin{aligned}
& \text { (V_b-V_B is not positive definite) }
\end{aligned}
$$

Source: Output developed by STATA

b) Breusch and Pagan Lagrangian multiplier test (Random Effect vs Pooled OLS):

This LM test suggesting decide between a Random effect and Pooled OLS regression has assumed the null hypothesis is that variance across estimates is zero which means there is no significant difference across units (i.e. no panel effect). According to the Chi-square value of 14.17 being statistically significant, we can reject the null hypothesis and deduce that there is a significant difference across the panels suggesting Random effect is better estimates than Pooled OLS as per the following output:

Table 08: Output of LM test

Breusch and Pagan Lagrangian multiplier test for random effects

$$
\begin{aligned}
& \text { nim[Banks, } t]=x b+u[B a n k s]+e[\text { Banks, t] } \\
& \text { Estimated results: }
\end{aligned}
$$

\begin{tabular}{r|rr} 
& var & sd $=$ sqrt(Var) \\
\hline $\operatorname{nim}$ & .0002285 & .0151151 \\
$\mathrm{e}$ & .000045 & .0067046 \\
$\mathrm{u}$ & 0 & 0
\end{tabular}

Test: $\quad \operatorname{var}(u)=0$

$$
\begin{array}{rc}
\operatorname{chi} 2(1)= & 14.17 \\
\text { Prob }>\text { chi2 }= & 0.0002
\end{array}
$$

Source: Output developed by STATA

7.7.2 Diagnostic Tests:

Several diagnostic tests have been performed in order to validate the model as depicted below:

\section{a) Test of Multicollinearity:}

None of the correlation is superior to 0.80 suggesting that any model doesn't suffer from the problem of multicollinearity as depicted from the following table: 
Table 09: Correlation Matrix

\begin{tabular}{r|rrrrrrr} 
& aoc & dora & $c r$ & size & i ip & ocbr & qm \\
\hline aoc & 1.0000 & & & & & & \\
dora & 0.5997 & 1.0000 & & & & & \\
cr & -0.2187 & -0.3033 & 1.0000 & & & \\
size & -0.0687 & -0.1862 & 0.2466 & 1.0000 & & \\
ijp & 0.5626 & 0.4580 & -0.3816 & -0.1717 & 1.0000 & & \\
ocbr & 0.2041 & 0.2688 & -0.0591 & -0.3292 & -0.0003 & 1.0000 & \\
qm & -0.4292 & -0.3667 & 0.8755 & 0.2810 & -0.5166 & -0.2605 & 1.0000 \\
inf1 & 0.1170 & 0.2092 & -0.2427 & -0.3674 & 0.1967 & -0.2480 & -0.2462 \\
& inf1 & & & & & & \\
inf1 & 1.0000 & & & & & &
\end{tabular}

Source: Output developed by STATA

\section{b) Testing for Heteroscadisticity:}

Following Chi-square value of 185.03 estimated from the output of modified Wald test for group wise heteroscadisticity is found statistically significant suggesting that we can reject the null hypothesis and deduce that the said fixed effect model suffers from the problem of non-constant error variance.

\section{Table 10: Output Wald Test}

Modified wald test for groupwise heteroskedasticity in fixed effect regression model

$\mathrm{HO}$ : $\operatorname{sigma}(i) \wedge 2=\operatorname{sigma\wedge 2}$ for al1 $i$

$\operatorname{chi2}(4)=185.03$

Prob $>$ Chi2 $=0.0000$

Source: Output developed by STATA

c) Unit Root test for Panel Settings:

We have adopted LLC test standing for Levin-Lin-Chu unit root test to know whether the mean, variance and covariance of series are stationary assuming the following hypothesis:

- $\mathrm{H}_{0}$ : The series is non-stationary or it has a stochastic trend

- $\mathrm{H}_{1}$ : The series is stationary or has a non-stochastic trend

Decision Rule: Reject $\mathrm{H}_{0}$ if the p-value of unit root tests less than significance level. Otherwise, do not reject $\mathrm{H}_{0}$. So, the adjusted t-value of -2.5051 is statistically significant suggesting that we can reject the null hypothesis and conclude that the dependent variable NIM is stationary as per the following table:

Table 11: Output of LLC Unit Root test

Levin-Lin-Chu unit-root test for nim

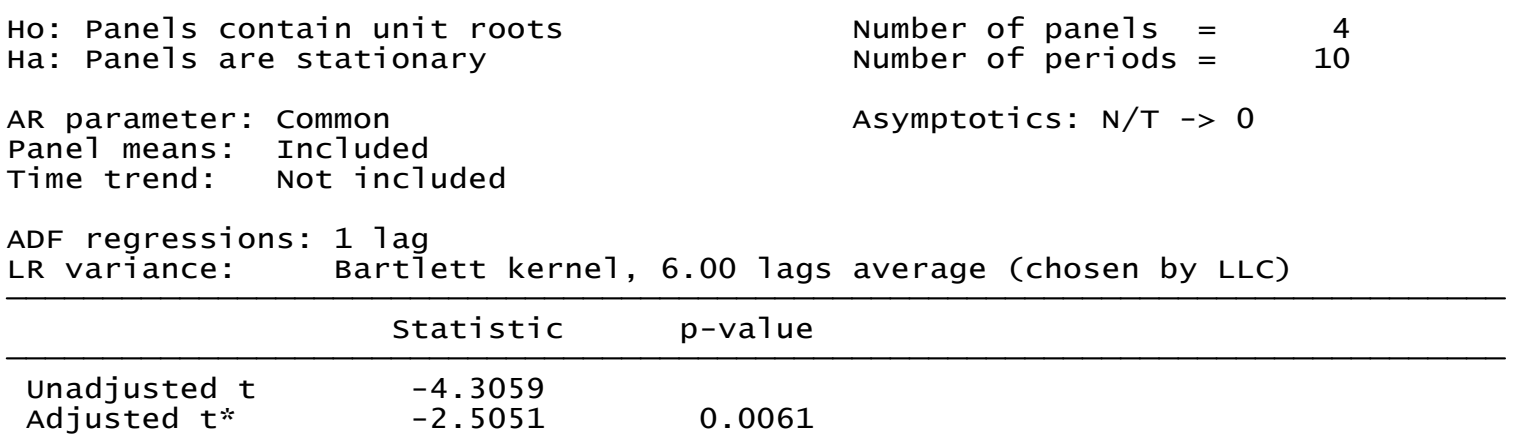

Source: Output developed by STATA

7.8 Major Findings

While conducting the report some major findings have been figured out from the analysis. The findings of the report are as follow:

$>$ The net interest margin position of Dhaka Bank Limited is satisfactory but it is in downgrading trend since 2016.

$>$ Dhaka Bank Limited and Basic Bank Limited are Liability Sensitive Organization. If the economy slows down, the interest will decrease and these sorts of banks will be benefited from this kind of situation. In contrast, Mercantile Bank Limited and Eastern Bank Limited are Asset Sensitive Organizations. These 
sorts of banks will be benefited if the rate of interest rises.

$>$ The gap between ISA and ISL is huge for Dhaka Bank Limited compared to other banks. The gap between ISA and ISL is increasing gradually which indicates that there is a lack management of interest sensitive assets and liabilities.

$>$ As Dhaka Bank Limited and Basic Bank Limited are Liability sensitive organizations, their relative IS Gap is less than zero. The relative IS Gap of Mercantile Bank Limited and Eastern Bank Limited are greater than zero as they are Asset Sensitive organizations. The relative IS Gap of Dhaka Bank Limited is very far from zero which is not a good sign compared to bank like Mercantile Bank Limited and Eastern Bank Limited.

$>$ The IS Ratio of Dhaka Bank Limited and Basic Bank Limited are less than 1 which means that they are Liability Sensitive Organizations. The banks like Mercantile Bank Limited and Eastern Bank Limited are Asset Sensitive Organizations as there is Ratio is more than 1. The IS Ratio of Dhaka Bank Limited is also not that much satisfactory compared to bank like Mercantile Bank Limited and Eastern Bank Limited because its IS Ratio is far less from 1 which also indicates that it is not managing its ISA and ISL properly.

$>$ Moreover, Degree of risk aversion, credit risk and quality of management are found individually statistically significant in explaining the variation of Net interest margin of these banks although all variables mentioned earlier are found statistically jointly significant in explaining the dependent variable measured with Net Interest Margin ratio of banks under Fixed effect, Random effect and Pooled OLS modeling revealing the causation between NIM and Bank specific along with macro-economic factors.

\section{Conclusion}

This paper has accomplished the objectives set at earlier stage by revealing how the changes of interest rate affect the Net interest margin (NIM) ratio which is one of the key profitability ratios of commercial banks due to the position of IS GAP followed by asset sensitive when RSA exceeds RSL and liability sensitive when RSA deficits RSL of balance sheet of four local commercial banks operating in Bangladesh. Although two banks consisting of Dhaka Bank and BASIC Bank out of four banks are found liability sensitive meaning liability will be affected more compared to assets when interest rate moves, the IS Gap of Dhaka Bank Limited is very far from zero which is not consistent compared to Mercantile Bank Limited and Eastern Bank Limited due to the managerial inefficiency of rate sensitive assets \& liability of Dhaka Bank Ltd. In addition, the variation in NIM ratio of these banks is also explained either individually or jointly by several bank specific as well as macro-economic factors as described earlier depending on the estimation of coefficients using fixed effect, random effect and pooled OLS model in order to divulge the causation between NIM and these factors.

\section{References}

Ahmed, A. S., Beatty, A., \& Takeda, C. (1997). Evidence on interest rate risk management and derivatives usage by commercial banks. Available at SSRN 33922.

Beutler, T., Bichsel, R., Bruhin, A. and Danton, J., 2015. The Impact of Interest Rate Risk on Bank Lending (No. 15.05). Working Paper, Study Center Gerzensee.

Bierwag GO, Fooladi IJ. Duration analysis: An historical perspective. Journal of Applied Finance. 2006 Oct $1 ; 16(2): 144$

Dash, M., \& Pathak, R. (2009). A Linear Programming Model for Assessing Asset-Liability Management in Banks. Available at SSRN 1542776.

David CA, Sinkey JF (1998) The use of interest rate derivatives by end users: The case of large community banks. Journal of Financial Services Research 14: 17-34

Deng, R. (2011). The Research on Interest Rate Risk of China’s Commercial Banks. Financial Theory and Practice, (2), $72-73$

Dhanani, A., Fifield, S. G. M., Helliar, C. V., \& Stevenson, L. A. (2005). Interest rate risk management-an investigation into the management of interest rate risk in UK companies. The Chartered Institute of Management Accountants 26 Chapter Street London SW1P 4NP, 2(4).

Galai, D., Ruthenberg, D., Sarnat, M., \& Schreiber, B. Z. (Eds.). (1999). Risk Management and Regulation in Banking: Proceedings of the International Conference on Risk Management and Regulation in Banking (1997). Springer Science \& Business Media

Mujeri \& Younus (2009) An Analysis of Interest Rate Spread in the Banking Sector. The Bangladesh Development Studies, XXXII ( 4) ,9-14 [Accessed 24 july,2018]

P.Allen May (2000) Increasing Interest Rate Risk at Community Bank and Thrifts: Analysis of Emerging Risks In Banking FDIC, Division of Insurance, [online] 4(3),12-22 Available from: https://www.fdic.gov/bank/analytical/bank/bt_0001.pdf [Accessed 24 July,2018]

Lalon M. Raad, Kabir B. Md. Interest Rate Risk Management of Commercial Banks in Bangladesh Based on IS (Interest Sensitivity) GAP Analysis. International Journal of Economics, Finance and Management Sciences. 
Vol. 5, No. 1, 2017, pp. 15-23. doi: 10.11648/j.ijefm.20170501.12

Ranjan, R., \& Nallari, R. (2004). Study of asset liability management in Indian banks canonical correlation analysis. Spandan-2014.

Reeta (2013) Measurement and Management strategies of Interest Rate RiskA Study in Indian Perspective. GGGI Management Review 1: 7-11.

Srivastava S, Srivastava D (2015) Interest Rate Risk Management: A Comparative Study of State Bank of India and ICICI Bank. International Journal of Management and Social Sciences Research (IJMSSR) 4.

Williamson, G. 2008. Interest Rate Risk Management: a Case Study of GBS Mutual Bank. Rhodes University. Accessed 03.09.2012. http://eprints.ru.ac.za/1585/1/williamson-final.pdf

Zhou, Yun, and Xiaosong Zheng. "A Study of Commercial Banks Interest Rate Risk Management under Interest Rates Liberalization." International Conference on Transformations and Innovations in Management (ICTIM 2017). Atlantis Press, 2017

Dhaka Bank Limited Annual Report (2013-2017) [Online] Available From: http://www.dbl.com

Bangladesh Bank Annual Report (2017) [Online] Available From: http://www.bb.org

\section{Appendix}

Table 12: Regression Output with Random effect GLS (Generalized Least Square) Method:

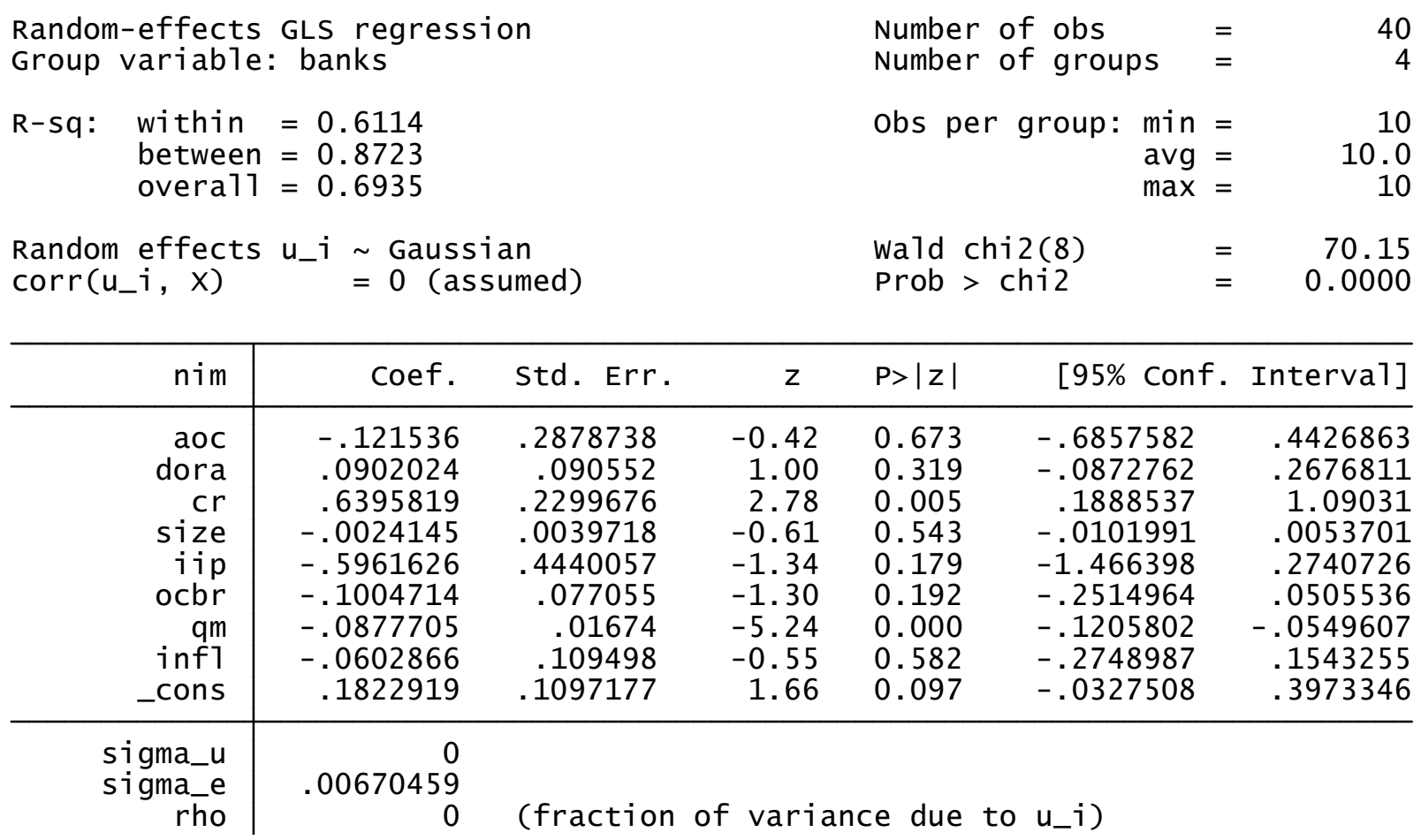

Source: Output developed by STATA 
Table 13: Regression Output with Fixed Effect Method:

Fixed-effects (within) regression Group variable: banks

$\begin{aligned} \text { R-sq: } & \text { within }=0.6913 \\ \text { between } & =0.5377\end{aligned}$ overa11 $=0.6047$

$\operatorname{corr}\left(u_{-} i, x b\right)=0.0941$

$\begin{array}{llr}\text { Number of obs } & = & 40 \\ \text { Number of groups } & = & 4 \\ \text { Obs per group: } \min & = & 10 \\ \mathrm{avg} & = & 10.0 \\ \max & = & 10 \\ & = & 7.84 \\ \mathrm{~F}(8,28) & = & 0.0000\end{array}$

\begin{tabular}{r|rrrrrr}
\hline nim & Coef. & std. Err. & $\mathrm{t}$ & $\mathrm{P}>|\mathrm{t}|$ & [95\% Conf. Interva1] \\
\hline aoc & -.0981744 & .2274901 & -0.43 & 0.669 & -.5641667 & .3678179 \\
dora & .17983 & .0760477 & 2.36 & 0.025 & .0240534 & .3356067 \\
cr & .4223695 & .1801356 & 2.34 & 0.026 & .0533785 & .7913606 \\
size & -.0049442 & .0034615 & -1.43 & 0.164 & -.0120348 & .0021463 \\
ijp & .0365393 & .4005673 & 0.09 & 0.928 & -.7839855 & .8570642 \\
ocbr & -.1337655 & .0715614 & -1.87 & 0.072 & -.2803523 & .0128214 \\
qm & -.0600901 & .0140832 & -4.27 & 0.000 & -.0889382 & -.0312421 \\
inf1 & -.107387 & .0851288 & -1.26 & 0.218 & -.2817654 & .0669915 \\
_cons & .2068883 & .0969968 & 2.13 & 0.042 & .0081993 & .4055773 \\
sigma_u & .00872506 & & & & \\
sigma_e & .00670459 & & & & \\
rho & .62873941 & (fraction of variance due to u_i) & \\
\hline
\end{tabular}

$F$ test that a11 $u_{-} i=0: \quad F(3,28)=10.92$

Prob $>F=0.0001$

Source: Output developed by STATA

Table 14: Regression output with Pooled OLS Method:

- reg nim aoc dora cr size iip ocbr qm infl

\begin{tabular}{r|crc} 
Source & SS & df & MS \\
\hline Mode1 & .006179305 & 8 & .000772413 \\
Residua1 & .002730868 & 31 & .000088093 \\
\hline Tota1 & .008910173 & 39 & .000228466
\end{tabular}

$\begin{array}{llr}\text { Number of obs } & = & 40 \\ \mathrm{~F}(8, \quad 31) & = & 8.77 \\ \text { Prob }>\mathrm{F} & = & 0.0000 \\ \text { R-squared } & = & 0.6935 \\ \text { Adj R-squared } & = & 0.6144 \\ \text { Root MSE } & = & .00939\end{array}$

\begin{tabular}{r|rrrrrr}
\hline nim & Coef. & std. Err. & $t$ & $\mathrm{P}>|\mathrm{t}|$ & [95\% Conf. Interva1] \\
\hline aoc & -.121536 & .2878738 & -0.42 & 0.676 & -.7086584 & .4655865 \\
dora & .0902024 & .090552 & 1.00 & 0.327 & -.0944796 & .2748844 \\
cr & .6395819 & .2299676 & 2.78 & 0.009 & .1705599 & 1.108604 \\
size & -.0024145 & .0039718 & -0.61 & 0.548 & -.010515 & .005686 \\
iip & -.5961626 & .4440057 & -1.34 & 0.189 & -1.501718 & .309393 \\
ocbr & -.1004714 & .077055 & -1.30 & 0.202 & -.2576261 & .0566833 \\
qm & -.0877705 & .01674 & -5.24 & 0.000 & -.1219119 & -.0536291 \\
inf1 & -.0602866 & .109498 & -0.55 & 0.586 & -.2836092 & .163036 \\
_cons & .1822919 & .1097177 & 1.66 & 0.107 & -.0414788 & .4060626 \\
\hline
\end{tabular}

Source: Output developed by STATA 
Table 15: Descriptive statistics

- xtsum aoc dora cr size iip ocbr qm inft nim

\begin{tabular}{|c|c|c|c|c|c|c|c|}
\hline \multicolumn{2}{|c|}{ Variable } & \multirow{2}{*}{$\frac{\text { Mean }}{.0240432}$} & \multirow{2}{*}{$\begin{array}{l}\text { Std. Dev. } \\
.0078409 \\
.0067767 \\
.0051141\end{array}$} & \multirow{2}{*}{$\begin{array}{l}\text { Min } \\
2673 \\
0116 \\
8732\end{array}$} & \multirow{2}{*}{$\begin{array}{r}\text { Max } \\
.0435929 \\
.0332838 \\
.0343523\end{array}$} & \multicolumn{2}{|c|}{ Observations } \\
\hline aoc & $\begin{array}{l}\text { overal1 } \\
\text { between } \\
\text { within }\end{array}$ & & & & & $\begin{array}{l}\mathrm{N}= \\
\mathrm{n}= \\
\mathrm{T}=\end{array}$ & $\begin{array}{r}40 \\
4 \\
10\end{array}$ \\
\hline dora & $\begin{array}{l}\text { overal1 } \\
\text { between } \\
\text { within }\end{array}$ & .0834359 & $\begin{array}{l}.0234027 \\
.0188169 \\
.0165928\end{array}$ & $\begin{array}{l}.0384484 \\
.0713493 \\
.050535\end{array}$ & $\begin{array}{l}1472642 \\
.1114639 \\
.1457151\end{array}$ & $\begin{array}{l}\mathrm{N}= \\
\mathrm{n}= \\
\mathrm{T}=\end{array}$ & $\begin{array}{r}40 \\
4 \\
10\end{array}$ \\
\hline $\mathrm{cr}$ & $\begin{array}{l}\text { overa11 } \\
\text { between } \\
\text { within }\end{array}$ & .0129057 & $\begin{array}{l}.0166252 \\
.0058275 \\
.0158201\end{array}$ & $\begin{array}{r}0 \\
.0081405 \\
-.0084762\end{array}$ & $\begin{array}{l}.1027357 \\
.0213819 \\
.0942595\end{array}$ & $\begin{array}{l}\mathrm{N}= \\
\mathrm{n}= \\
\mathrm{T}=\end{array}$ & $\begin{array}{r}40 \\
4 \\
10\end{array}$ \\
\hline size & $\begin{array}{l}\text { overal1 } \\
\text { between } \\
\text { within }\end{array}$ & 25.33746 & $\begin{array}{r}477073 \\
.1029151 \\
.4684563\end{array}$ & $\begin{array}{l}24.09954 \\
25.18952 \\
24.24748\end{array}$ & $\begin{array}{l}26.13594 \\
25.41674 \\
26.05665\end{array}$ & $\begin{array}{l}\mathrm{N}= \\
\mathrm{n}= \\
\mathrm{T}=\end{array}$ & $\begin{array}{r}40 \\
4 \\
10\end{array}$ \\
\hline iip & $\begin{array}{l}\text { overal1 } \\
\text { between } \\
\text { within }\end{array}$ & .0193592 & $\begin{array}{l}.0047597 \\
.0040597 \\
.0031587\end{array}$ & $\begin{array}{l}.0093315 \\
.0152605 \\
.0121052\end{array}$ & $\begin{array}{l}.0281742 \\
.0236126 \\
.0314719\end{array}$ & $\begin{array}{l}\mathrm{N}= \\
\mathrm{n}= \\
\mathrm{T}=\end{array}$ & $\begin{array}{r}40 \\
4 \\
10\end{array}$ \\
\hline ocbr & $\begin{array}{l}\text { overal1 } \\
\text { between } \\
\text { within }\end{array}$ & .0370473 & $\begin{array}{r}.028843 \\
.0204433 \\
.0225928\end{array}$ & $\begin{array}{l}.0035743 \\
.0097843 \\
.0028591\end{array}$ & $\begin{array}{l}.1303553 \\
.0541471 \\
.1343968\end{array}$ & $\begin{array}{l}\mathrm{N}= \\
\mathrm{n}= \\
\mathrm{T}=\end{array}$ & $\begin{array}{r}40 \\
4 \\
10\end{array}$ \\
\hline qm & $\begin{array}{l}\text { overa11 } \\
\text { between } \\
\text { within }\end{array}$ & .9566775 & $\begin{array}{l}.2608307 \\
.1608689 \\
.2193761\end{array}$ & $\begin{array}{l}.743919 \\
.8468242 \\
.5047861\end{array}$ & $\begin{array}{r}2.248719 \\
1.19581 \\
2.009586\end{array}$ & $\begin{array}{l}\mathrm{N}= \\
\mathrm{n}= \\
\mathrm{T}=\end{array}$ & $\begin{array}{r}40 \\
4 \\
10\end{array}$ \\
\hline infl & $\begin{array}{l}\text { overa11 } \\
\text { between } \\
\text { within }\end{array}$ & .06863 & $\begin{array}{r}.0176962 \\
0 \\
.0176962\end{array}$ & $\begin{array}{r}.0542 \\
.06863 \\
.0542\end{array}$ & $\begin{array}{r}.114 \\
.06863 \\
.114\end{array}$ & $\begin{array}{l}\mathrm{N}= \\
\mathrm{n}= \\
\mathrm{T}=\end{array}$ & $\begin{array}{r}40 \\
4 \\
10\end{array}$ \\
\hline nim & $\begin{array}{l}\text { overa11 } \\
\text { between } \\
\text { within }\end{array}$ & .0306038 & $\begin{array}{l}.0151151 \\
.0126923 \\
.0102249\end{array}$ & $\begin{array}{r}-.019468 \\
.0129709 \\
-.0018351\end{array}$ & $\begin{array}{r}.0524 \\
.04325 \\
.0498829\end{array}$ & $\begin{array}{l}\mathrm{N}= \\
\mathrm{n}= \\
\mathrm{T}=\end{array}$ & $\begin{array}{r}40 \\
4 \\
10\end{array}$ \\
\hline
\end{tabular}

Source: Output developed by STATA 